\title{
Malaysian Undergraduates' Perceptions of Online Approach via Skype in Developing Speaking Skills
}

\author{
https://doi.org/10.3991/ijim.v15i18.24543 \\ Sarala Thulasi Palpanadan ${ }^{1(\bowtie)}$, Iqbal Ahmad², Tamil Selvan A/L Subramaniam ${ }^{1}$ \\ ${ }^{1}$ Universiti Tun Hussein Onn Malaysia, Johor, Malaysia \\ ${ }^{2}$ University of Malakand, Khyber Pakhtunkhwa, Pakistan \\ sarala@uthm. edu.my
}

\begin{abstract}
Speaking skill pedagogy has always remained a huge enigma for English as a Second Language (ESL) educators. Despite the challenges, the need to master the skills prevail in academia. The undergraduates especially those from the technical division seem to grapple with the ability to perform well in their studies and market their products upon employment due to the inability to communicate well in English. Nowadays, there are numerous platforms available for ESL learners to improve their speaking proficiency. Thus, this paper intended to study the effectiveness of using Skype as an online platform to help students enhance their confidence in speaking in English. 100 reflective journals of first year undergraduates who enrolled in an English course were collected. Meanwhile, 10 undergraduates were randomly selected to participate in the semi-structured interview. All the participants' reflections and views were analyzed and thematized using Transana software. Four main themes emerged: account possession; familiarity; challenges; and features. It was found that many participants were aware of Skype but did not have the account prior to the study. Majority of the participants admitted that Skype activities helped them to converse better which enhanced their motivation to speak in English more confidently and fluently.
\end{abstract}

Keywords—Skype, speaking skills, online platforms, perceptions, Malaysian undergraduates

\section{Introduction}

The applications of online teaching and learning tools are increasingly becoming the focus of attention nowadays in all walks of life [1], [2]. Besides, the evolution of Web 2.0 technology has accommodated the progress of social media as a mean of communication which has paved platforms for various types of interaction [3]. Thus, numerous social media applications such as laptops, mobile phones and other social media applications have gained attention as tools used to engage in interaction especially in the world of academia including language learning entity. Language learning is an interactive activity that can be performed effectively using numerous 
internet based tools which are currently available [4], [5]. Online learning provides enormous opportunities for learners' language skills development [6] where there have been a proliferation of research conducted to investigate the effects of employing social media to support language learners to enhance their language skills and proficiency.

One of the online platforms used in communication is the Skype technology [7]. This software helps in creating wider scope for the users including students to learn English language as they are able to find better and wider coverages through online interaction. There are enough empirical evidences about the technological use of Skype for learning and its importance for students [8]. However, this important social interaction tool has not been effectively used by language teachers for promoting language skills of students. There is an intense need to explore the maximized impact of Skype technology on students' English language learning skills development. English language teaching using online Skype approach may allow English language teachers and students all over the world to connect in new ways. It has the potential to open opportunities for English teachers who want to improve students' language learning skills. But successful online teaching and learning is not an easy task. It has many pitfalls and requires effective approach to be accomplished effectively [9]. This study aims to evaluate the use and impact of Skype approach on Malaysian university students' especially in learning speaking skills in English.

\section{$2 \quad$ Literature review}

Technology is increasingly used in all fields of life including teaching and learning. Studies have highlighted that instructions conducted online have better impact on students' learning, especially in language development [10]; [11]. Research has further revealed that students who are engaged in an online English language learning show better results than those who are taught in traditional classroom language learning [12]. Nowadays, it is common for undergraduates to online facilities in studies as the universities provide free access to internet and thus, they are very familiar with many online learning sources including Twitter, WhatsApp and Instagram. Apparently, educators and students are becoming more and more familiar with online platforms in participating in teaching and learning activities via various online platforms such as Google Meet, Author and Skype. Research has shown that language students using technology and social media sources possess more advantages in terms of the four language skills (listening, reading, writing, and speaking) in English [13]. Apparently, students with access to online learning possess wider command of vocabulary and deeper conceptual understanding of English language including grammar rules due to the continuous practice of using online approach.

Among language learning skills, speaking is an active skill for which the speaker needs direct and immediate interaction with others during communication process. This skill can be effectively polished through online approach [14]. Speaking refers to communication between and among different people whether it is performed face to face or using other sources such as mobile phone, WhatsApp, Facebook, and Skype [15]. However, many English language learners attempt to enhance their speaking skills but 
in a traditional learning environment where they do not have opportunities for better interactions to practice compared to online learning environment. Some teachers in Vietnam have introduced online oral diaries using online platforms including Skype as an essential element of second language learning that allowed the teachers and students to have more personal use of the language in a professional manner [16]. Skype is an online tool of social media which can be used by English teachers for improving language proficiency of students both in audio and video forms. A research study revealed that in the last decade around 124 million people used Skype by placing 95 million calls including $40 \%$ video calls [17]. Therefore, online learning is practised more profoundly to pave paths for learners to communicate more.

\subsection{The practice of Skype in language learning}

In the current technologically developed and globalized world, Skype is useful for making classroom interactions meaningful and knowing about the world [18]. Skype is an online social media tool which is used mostly for audio video calls. It is an important tool which brings many benefits, mainly, for teachers and students of English as a second language (ESL) or English as a foreign language (EFL). Skype call is free of charge and service-based that can be incorporated into classroom instructional plan and also used for exchanging cross cultural experiences. Besides, utilizing this platform to polish speaking practices with friends and course mates, Skype is also widely used as platforms for conferences presentations where informative file and screen sharing can be done with other English language learners while making calls. In addition, it becomes a useful tool that provides an instance messaging option for English language students who prefer writing to speaking [18].

Teaching via Skype may help English language teachers in connecting to wider communities [19]. As an important source of online learning, Skype can be used by young university students to share important information and idea with colleagues, teachers and media who are not available face to face. It enables English language teachers to create a student friendly atmosphere to discuss various types of topics in a more authentic manner, prepare more interesting lessons using audio and video to convey information and carry out discussions [20]. It is one of the social media tools which can be used for recording calls and listening or watching video records for more clarifications to understand more complex language content which is clear during classroom interaction. Research has indicated that connecting through Skype opens new ways of learning for students to wider media and audiences [21]. As a technology tool Skype has test call features as it helps teachers in measuring voice clarity, noises in the backgrounds and other important elements of the digital classroom experiences. The current year has ushered in a digital innovation period where tools like Skype can be very useful but it may have some limitations like poor internet connectivity, poor speed for teachers and students of English language learning classroom [22]; [23]. However, despite this limitation, Skype is a useful technological tool that can facilitate language teachers and students in numerous ways to learn English language skills more meaningfully. 


\subsection{Theoretical background of Skype in language learning}

The use of social media platform can be employed in teaching and learning via computers, laptops and mobile phone. Computer-assisted language learning (CALL) has been a practice since the 20th century and mobile-assisted language learning (MALL) has gained popularity in the 21 st century. The mobile learning (mLearning) has many common aspects as featured in CALL [24]. Researchers claim that MALL has helped students to improve their language skills including speaking skills effectively [25]. In addition, this is the best time to incorporate MALL as it offers great opportunities to the language teachers and learners to ensure learning takes place sufficiently. The current generation including the university students is found to possess mobile phones more profoundly. Thus, language learning can be materialized where students can access English learning materials and resources by using their mobile devices, such like smart phones and iPhone regardless of time and location limit [26]. In addition, real-life communication should also be integrated in communicative language teaching (CLT) classrooms [27]. This includes the audio-visual tools including videos, discussions and images that are utilized in the classrooms to enhance the language learning outcome [28] to provide more authentic feel of the classroom to enhance students' motivation to learn [29]. Thus, the practice of online platform using Skype in ESL classrooms may provide room for learners including university students to perform speaking skills more rigorously.

\section{$3 \quad$ Methodology/materials}

This qualitative research involved 100 selected undergraduates from a technical university in Malaysia. The participants consisted of undergraduates who were in their degree programs and enrolled in English courses at the university. The participants were introduced to various types of online platforms during the lessons and asked to prepare a reflective journal to state their perceptions of using Skype activities as an online platform to conduct presentations and practice speaking skills. They were told to write reflections based on their individual experiences without the influence of any other parties. Their reflections were collected immediately after the completion of the online speaking class as to ensure participants could remember the details of the sessions clearly. Next, ten participants were randomly selected to participate in a semi-structured interview session to provide their perceptions of using Skype as a platform to learn speaking skills. Thematic analysis was conducted to determine the students' perceptions of the effectiveness of using Skype platform during the speaking lessons in English. The emerged themes were validated by three experts of the same field (teaching and learning). Based on the themes identified, further actions could be taken to enhance speaking skills of university students using related online platforms.

\section{$4 \quad$ Results and findings}

Thematic analysis was conducted on the data collected which included the students' reflections and interview transcription. Since there was no face to face interaction due to the Covid-19 pandemic lockdown, all the reflections prepared by students were asked 
to email to the researchers for analysis. The interviews were conducted via telephone calls and online meetings. 100 written reflection and 10 interview transcriptions were analyzed and coded. Based on the analysis four (4) themes emerged: account possession; familiarity; features; and challenges.

\subsection{Account possession}

Based on the findings, only about $38 \%$ (38 out of 100) of the participants possessed Skype account prior to the class session. Thus, more than half of them $(62 \%)$ did not seem to have activated Skype account before the course. Those participants who did not have the Skype account earlier mentioned that they created the account as they were to do so by the lecturer in order to conduct the speaking activity via Skype. The speaking task was one the course requirement where students had to perform academic discussion using a selected online platform. Finally, all the students managed to create, activate and participate in the online academic discussions using the medium of Skype.

\subsection{Familiarity}

Many participants shared that they have heard about Skype but have not used it before $(62 \%)$. Some participants $(10 \%)$ mentioned that they had account and were using it earlier but not using it currently. Some students $(28 \%)$ had the account but only used it a few years ago to communicate with oversea friends or relations. Some of the participants' responses are given in Table 1.

Table 1. Participants' sample views for familiarity theme

\begin{tabular}{|l|l|}
\hline \multicolumn{1}{|c|}{ Participants' Responses } & \multicolumn{1}{c|}{ Theme - Familiarity } \\
\hline $\begin{array}{l}-/ \text { No/ } \\
-/ \text { I know about this platform but never tried before/ }\end{array}$ & Heard but never used before \\
\hline $\begin{array}{l}-/ \text { Yes/ } \\
-/ \text { Yes, but forgotten/ }\end{array}$ & Know about Skype and used before but not now \\
\hline $\begin{array}{l}-/ \text { Yes, but rarely/ } \\
-\end{array}$ & Kes, sometimes, to contact friends and relations \\
from oversea/ & \\
\hline
\end{tabular}

\subsection{Features}

Many students were found to like using this platform. The reasons included the setting of the platform such as the feeling of being in class where their course mates were seated next to them, has better features, interesting, having creative patterns and lively background filter. Some participants shared that they could discuss freely without feeling shy as it is not really a face to face activity but provides the environment of being in class. They shared that it was a good opportunity to practice more speaking situations for them. Table 2 shows some of the participants' views. 
Table 2. Participants' sample views for features theme

\begin{tabular}{|l|l|}
\hline \multicolumn{1}{|c|}{ Participants' Responses } & Theme - Features \\
\hline- /has many interesting features/ & Interesting features \\
- /many new settings; more colourful/ & \\
- /fun and can try filters as well/ & \\
\hline- /good approach because faces are seen on one page. It is not like just talking & $\begin{array}{l}\text { Discussion of topics } \\
\text { (spe the screen/ }\end{array}$ \\
- /can see the class view like everybody is sitting in a class; can discuss in a \\
$\quad$ large group and crack jokes as well/ & \\
- /gives a feel of being in classroom physically, can share opinion easily/ \\
- /able to discuss with friends easily without feeling shy/ \\
- /can use this method to speak more with friends and lecturers/ & \\
\hline- /can learn to use within a short time/ & \\
- /fun way of learning/ & \\
- /very good, easy to use and understand/ & Learning pace \\
- /can take my own time to learn and practice/ & \\
\hline
\end{tabular}

\subsection{Challenges}

Some students mentioned that there were some challenges in using Skype to communicate. The issues highlighted included that they were not able to get connection easily compared to other platforms such as Google Meet (GM), the sound system was not appealing and the need to download the software prior to using the platform. Some participants were not interested as it was not widely used in the classroom and they needed more time to learn the functions as the platform was new to them. Some complained that using the software had caused their mobile phones' battery to drain faster. Table 3 shows some of the participants' views.

Table 3. Participants' sample views for challenges theme

\begin{tabular}{|l|l|}
\hline \multicolumn{1}{|c|}{ Participants' Responses } & Theme - Challenges \\
\hline $\begin{array}{l}\text { - /Need to download software first/ } \\
-/ \text { consumes a lot of date usage for downloading; drains battery faster/ }\end{array}$ & Software issues \\
\hline $\begin{array}{l}- \text { /uncommonly used; most lecturers use other platforms such a Google Meet/ } \\
- \text { /most of my friends use other platforms such as GM/ }\end{array}$ & $\begin{array}{l}\text { Not widely used in } \\
\text { classrooms currently }\end{array}$ \\
\hline $\begin{array}{l}- \text { /lagging/ } \\
-/ \text { takes time to identify who is communicating/ }\end{array}$ & Time consuming \\
\hline
\end{tabular}

\section{Conclusion}

Generally, integrating information technology and online platforms are no longer a privilege but has become a necessity in the current academia. Besides, the benefits of using online platforms and information technology in education system has been emphasized in Malaysia even before the issue of Covid-19 [30]. Thus, the perceptions 
of students of the effectiveness of using online platforms such as Skype need to be taken into consideration to help the educators improvise their lessons and strategies in pedagogy. Apparently, using Skype as the online platform to learn speaking skills in English was rather a new experience for many university students who were involved in this study. However, they were excited to explore it and managed to create, activate and utilize the account and platform effortlessly. Since most of the classes were conducted online due to the Covid-19 pandemic scenario currently, trying out new a platform was not a tough matter for the students, especially applications related to using their mobile phones. Thus, they were mentally and physically ready to use any platforms suggested by their lecturers for classrooms or any form of academic purposes.

Generally the university students who participated in this study found the sessions interesting and became fascinated by the features that Skype had to offer that seemed to have captured their interests mainly as it provided the real classroom environment to them. As a matter of fact, the students also enjoyed participating in the speaking activities more vigorously as they felt they were communicating with their course mates and the lecturer for real. Thus, the students had the opportunity to participate in the discussion and question and answer sessions more meaningfully. The findings of this study were also in line with the findings of the study conducted by Yang, (2020) who found that assimilating social media application such as Tik Tok into language classroom has enhanced the learners' motivation and interests to master skills in English where the learners were intrigued to master the language beyond the classroom. As a matter of fact, learners may develop their confidence to speak in public when their motivation towards communicating in English is established. Besides improving language skills, students also felt motivated and had more confidence. This finding was also supported by researches who used other online platform such as Facebook to enhance students' motivation and confidence to communicate in English [31]. This type of motivation is important for students who are shy to speak particularly face to face with others but intend to improve their communication skill. These types of students may also opt for Skype as a platform to improve their skills in English until they develop enough ability to speak in English confidently.

On the other hand, some participants particularly the first-time users, had highlighted some challenges or issues in using the Skype as a platform during the learning session. However, they still managed to $\log$ in and participate in the speaking activities once their technical issues were resolved. Thus, based on the four themes that emerged from the study (account possession, familiarity, features, and challenges), it can be concluded that majority of the students enjoyed the speaking lessons using Skype as the online platform despite the fact that many of them were not aware of the details the platform well and faced some familiarization issues. Students who are shy to speak face to face with others but intend to improve their communication skill may opt for Skype as a platform to improve their skills in English until they develop strength to speak confidently. Therefore, more classes or learning sessions should be conducted using Skype as the learning platform so that students obtain more opportunity to communicate with their course mates and improve their speaking abilities in English.

On the other hand, the study had a limitation where only two sessions were conducted using Skype due to time constraint for researchers and participants. However, 
the reflections of all the participants were analysed carefully to ensure all the necessary points were noted for the study. Thus, in future, more in-depth research involving more participants and other language skills using Skype sessions could be conducted to get more robust data for analysis.

\section{Acknowledgement}

This research work is supported by UTHM TIER 1 Grant (H807).

\section{$7 \quad$ References}

[1] V. Singh and A. Thurman, "How Many Ways Can We Define Online Learning? A Systematic Literature Review of Definitions of Online Learning (1988-2018)," Am. J. Distance Educ., vol. 33, no. 4, pp. 289-306, 2019, doi: https://doi.org/10.1080/08923647.2019.1663082

[2] A. H. Albashtawi and K. B. Al Bataineh, "The Effectiveness of Google Classroom Among EFL Students in Jordan: An Innovative Teaching and Learning Online Platform," Int.J.Emerg. Technol.Learn., vol. 15, no. 11, pp. 78-88, 2020, doi: https://doi.org/10.3991/ijet .v15i11.12865

[3] D. Zeng, H. Chen, R. Lusch, and S. H. Li, "Social Media Analytics and Intelligence," IEEE Intell. Syst., vol. 25, no. 6, pp. 13-16, 2010, doi: https://doi.org/10.1109/MIS.2010.151

[4] E. Ushida, "The Role of Students' Attitude and Motivation in Second Language Learning in Online Language Courses," CALICO J., vol. 23, no. 1, pp. 1-30, 2005. https://doi . org $/ 10.1558 /$ cj.v23i1.49-78

[5] N. M. Terhune, "Language Learning Going Global: Linking Teachers and Learners via Commercial Skype-Based CMC," Comput. Assist. Lang. Learn., vol. 29, no. 6, pp. 1071-1089, 2016, doi: https://doi.org/10.1080/09588221.2015.1061020

[6] N. S. Jayanthi and R. V. Kumar, "Use of ICT in English Language Teaching and Learning," J. English Lang. Lit., vol. 3, no. 2, pp. 34-38, 2016.

[7] J. Reinhardt, "Metaphors for Social Media-Enhanced Foreign Language Teaching and Learning," Foreign Lang. Ann., vol. 53, no. 2, pp. 234-242, 2020, doi: https://doi .org/10.1111/flan.12462

[8] J. Choi and Y. Yi, "Teachers' Integration of Multimodality Into Classroom Practices for English Language Learners," TESOL J., vol. 7, no. 2, pp. 304-327, 2016, doi: https://doi. org/10.1002/tesj.204

[9] N. O. Hussein and A. I. Elttayef, "The Impact of Utilizing Skype as a Social Tool Network Community on Developing English Major Students' Discourse Competence in the English Language Syllables," J. Educ. Pract., vol. 7, no. 11, pp. 29-33, 2016.

[10] M. Angelova and Y. Zhao, "Using an Online Collaborative Project between American and Chinese Students to Develop ESL Teaching skills, Cross-Cultural Awareness and Language Skills," Comput. Assist. Lang. Learn., vol. 29, no. 1, pp. 167-185, 2016, doi: https://doi.org /10.1080/09588221.2014.907320

[11] M. González-Lloret, "Collaborative Tasks for Online Language Teaching," Foreign Lang. Ann., vol. 53, no. 2, pp. 260-269, 2020, doi: https://doi.org/10.1111/flan.12466

[12] D. Chun, B. Smith, and R. Kern, "Technology in Language Use, Language Teaching, and Language Learning," Mod. Lang. J., vol. 100, pp. 64-80, 2016, doi: https://doi.org/10.1111/ modl. 12302

[13] J. A. Arani, "Advancing Academic Writing in a Mobile Skype-Based Blended Model," Int. J. Interact. Mob. Technol., vol. 12, no. 3, pp. 86-103, 2018, doi: https://doi.org/10.3991/ ijim.v12i3.8219 
[14] H. Parris and L. M. Estrada, "Digital Age Teaching for English Learners," Handb. TESOL K-12, pp. 149-162, 2019, doi: https://doi.org/10.1002/9781119421702.ch10

[15] M. A. A. Alkamel and S. S. Chouthaiwale, "The Use of ICT Tools in English Language Teaching and Learning: A Literature Review," J. English Lang. Lit., vol. 5, no. 2, pp. 29-33, 2018.

[16] T. Van Le, U. Cunningham, and K. Watson, "The Relationship Between Willingness to Communicate and Social Presence in an Online English Language Course," JALT CALL J., vol. 14, no. 1, pp. 43-59, 2018. https://doi.org/10.29140/jaltcall.v14n1.223

[17] O. Kozar, "Teaching Conversational English to Adult Learners via Skype: A Russian Perspective," Int. Perspect. Teach. Four Ski. ELT, pp. 125-137, 2018, doi: https://doi .org/10.1007/978-3-319-63444-9_9

[18] S. R. García Trejos, R. L. Diaz Pascuas, and M. T. Artunduaga Cuellar, "Las sesiones de Skype como una forma de proporcionar práctica oral adicional a los estudiantes universitarios de inglés TT - Skype sessions as a way to provide additional oral practice of English university students," Colomb. Appl. Linguist. J., vol. 20, no. 1, pp. 62-78, 2018. https://doi .org/10.14483/22487085.10826

[19] M. Milojković, "Teaching English by Skype: Theoretical and Practical Considerations from the Perspective of Serbian English Teachers," in Teaching Language and Teaching Literature in Virtual Environments, 2019, pp. 97-119. https://doi.org/10.1007/978-981-13-1358-5_6

[20] M. Tsukamoto, B. Nuspliger, and Y. Senzaki, "Using Skype (c) to Connect a Classroom to the World: Providing Students an Authentic Language Experience within the Classroom," in CamTESOL conference on English language teaching, 2009, vol. 5, pp. 162-168.

[21] Y. Furumura and H.-C. Huang, "The Effect of Online Exchanges via Skype on EFL Learners' Achievements," EuroCALL Rev., vol. 27, no. 2, p. 13, 2019, doi: https://doi.org/10.4995/ eurocall.2019.11128

[22] N. Punar and L. Uzun, "The Effect of the Skype TM Conference Call on English Speaking Anxiety," Int. Online J. Educ. Teach., vol. 6, no. 2, pp. 393-403, 2019.

[23] I. W. Husein and P. Purnawarman, "Low English Proficiency Students' Oral Interaction with Native Speaker Through Skype," J. Ilmu Pendidik. dan Pengajaran, vol. 6, no. 2, pp. 79-94, 2019.

[24] G. Stockwell and P. Hubbard, "Some Emerging Principles for Mobile-Assisted Language Learning," Int. Res. Found. English Lang. Educ., no. 2013, pp. 1-15, 2013.

[25] T. M. Miangah, "Mobile-Assisted Language Learning," Int. J. Distrib. Parallel Syst., vol. 3, no. 1, pp. 309-319, 2012, doi: https://doi.org/10.5121/ijdps.2012.3126

[26] H. Yang, "Secondary-School Students' Perspectives of Utilizing Tik Tok for English Learning in and Beyond the EFL Classroom," Aust. 2020 3rd Int. Conf. Educ. Technol. Soc. Sci. (ETSS 2020), no. Etss, p. 162, 2020.

[27] H. D. Brown, Principles of Language Learning and Teaching. White Plains, NY: Longman, 2000.

[28] H. J. Macwan, "Using Visual Aids as Authentic Material in ESL Classrooms," Res. J. English Lang. Lit., vol. 3, no. 1, pp. 91-96, 2015. https://doi.org/10.26417/ejls .v3i1.p96-99

[29] N. G. Mathew and A. O. H. Alidmat, "A Study on the Usefulness of Audio-Visual Aids in EFL Classroom: Implications for Effective Instruction," Int. J. High. Educ., vol. 2, no. 2, pp. 86-92, 2013, doi: https://doi.org/10.5430/ijhe.v2n2p86

[30] F. Rizal et al., "Comparison of ICT Using in Learning between Indonesia and Malaysia," J.Phys. Conf. Ser., vol.1387,no.1,2019, doi:https://doi.org/10.1088/1742-6596/1387/1/012133

[31] A. O. AbuSa'aleek, "Students' Perceptions of English Language Learning in the Facebook Context," Teach. English with Technol., vol. 15, no. 4, pp. 60-75, 2015. 


\section{Authors}

Sarala Thulasi Palpanadan, Center for Language Studies, Universiti Tun Hussein Onn Malaysia, 86400, Batu Pahat, Johor Malaysia. E-mail: sarala@uthm.edu.my.

Iqbal Ahmad, Department of Education, University of Malakand, Khyber Pakhtunkhwa 18800, Pakistan.

Tamil Selvan A/L Subramaniam, Universiti Tun Hussein Onn Malaysia, Johor, Malaysia.

Article submitted 2021-06-06. Resubmitted 2021-07-05. Final acceptance 2021-07-06. Final version published as submitted by the authors. 